\title{
Rare case of burkholderia liver abscess complicated by hepatobronchial fistula
}

\author{
Haritha Indulekha, ${ }^{1}$ Saurabh Chandrakar, ${ }_{1}^{1}$ Itish Patnaik, ${ }^{2}$ Nupur B Patel (i) ${ }^{1}$
}

${ }^{1}$ Department of Anaesthesiology and Critical Care Medicine, AllMS Rishikesh, Rishikesh, Uttarakhand, India 2Department of Gastroenterology, AllMS Rishikesh, Rishikesh, Uttarakhand, India

\section{Correspondence to}

Dr Nupur B Patel;

nupurbpatel@yahoo.co.in

Accepted 30 December 2021

\section{DESCRIPTION}

Even though there are few case reports of multidrugresistant burkholderia causing various infections in immunocompromised individuals, hepatobronchial fistula due to burkholderia is not reported. ${ }^{1-3}$

A 58-year-old man with no known comorbidities presented with a history of low-grade continuous fever and right-sided abdominal pain for 1 month. He had received tablet paracetamol prescribed by a general practitioner. But his symptoms did not subside, and he had increased fatigue, so he came to the hospital. On general examination, heart rate was $94 / \mathrm{min}$, blood pressure was $134 / 78 \mathrm{~mm} \mathrm{Hg}$ and temperature was $39^{\circ} \mathrm{C}$. Cardiac, pulmonary and abdominal examinations revealed no abnormality. Laboratory tests were remarkable for a leucocytosis $\left(15080\right.$ cells $\left./ \mathrm{mm}^{3}\right)$, total bilirubin $2.6 \mathrm{mg} / \mathrm{dL}$,

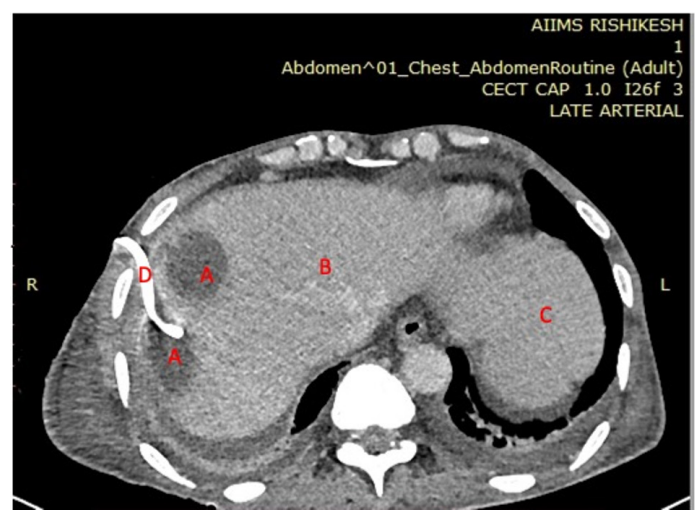

Figure 1 CT scan showing liver abscesses ( $A$-abscess, B-liver, C—stomach, D-drain).

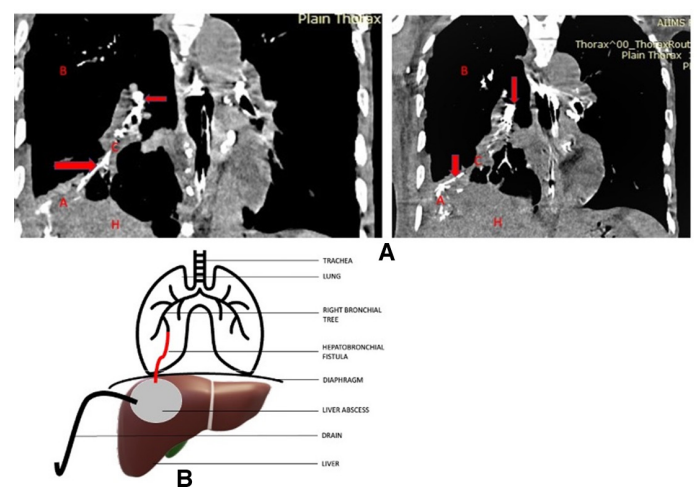

Figure 2 (A) Postcontrast CT after instillation of dye through the drain showing hepatobronchial fistula (red arrows), A-abscess, B-lung, C-hepatobronchial fistula, $\mathrm{H}$-liver). (B) Line diagram of hepatobronchial fistula. ${ }^{* *}$ Created by author using Microsoft PowerPoint online 3D models. Permission to reuse.

\section{Box 1 Common causes of fistulation}
1. Congenital.
2. Hepatic hydatid cysts.
3. Amoebic liver abscesses.
4. Pyogenic liver abscesses.
5. Biliary tract lithiasis.
6. Liver trauma.
7. Surgical complications.

alanine transferase $180 \mathrm{U} / \mathrm{L}$, aspartate transferase $72 \mathrm{U} / \mathrm{L}$. Chest X-ray showed an elevated right hemidiaphragm. The patient was admitted and treated with fluids, and empiric antibiotic therapy with piperacillin-tazobactam was started. Baseline investigations and blood cultures were taken.

An abdominal ultrasound (US) revealed two hypodense collections $(3.5 \mathrm{~cm}$ and $4 \mathrm{~cm}$ diameter in the right lobe of the liver. Subsequently, contrastenhanced CT (figure 1) showed few hypodense collections in both lobes of the liver for which percutaneous drainage was placed, yielding $80 \mathrm{cc}$ of purulent fluid. Entamoeba histolytica serology was negative. On analysis of the fluid,cartridge-based nucleic acid amplification test for tuberculosis and malignant cells were negative. Pus culture from the aspirate subsequently grew multidrug-resistant

\section{Box 2 Investigations of fistula}

1. Chest X-ray after instillation of water-soluble contrast material in the hepatic drain tube.

2. CT abdomen and thorax.

3. US abdomen.

4. Endoscopic retrograde cholangiopancreatography.

5. Percutaneous transhepatic cholangiography.

6. MRI.

7. Hepatobiliary iminodiacetic acid scan.

\section{Box 3 Priorities in treatment}

1. Antibiotics.

2. Conservative approach (spontaneous closure).

3. Minimally invasive surgery (percutaneous drainage and decompression of hepatic abscesses).

4. Radical surgery (lung decortication and diaphragm repair, liver wedge resection). 


\section{Box 4 Factors in fistula healing}

1. Early pus culture sensitivity testing and appropriate antibiotics.

2. Early percutaneous drainage and decompression of liver abscess.

3. Good nutritional status with high protein intake.

4. Good glycaemic control.

5. Early surgical intervention in patients not responding to minimally invasion surgery.

burkholderia cepacia. Antibiotics were broadened to high intravenous dose-extended meropenem infusion.

On day 8 of the hospital stay, he developed a dry cough, shortness of breath and a metallic taste in the mouth. We observed that lavage of the abscess caused cough with purulent discharge. Clinical suspicion of the hepatobronchial fistula was made. CT chest and abdomen were done after instillation of contrast through the drain, which revealed a fistulous tract between the liver abscess and the bronchus (figure 2). Hepatic drain decompression was done, and injection tigecycline was added. Over the next 10 days, the drain output gradually decreased. Follow-up CT after 1 month showed resolution of abscess and fistula.

Common causes of fistulation, investigations of fistula, priorities in treatment and factors in fistula healing are listed below (boxes 1-4).

Contributors NBP—planning, writing and submitting the case. HI, SC, IP—helped in writing the case.

Funding The authors have not declared a specific grant for this research from any funding agency in the public, commercial or not-for-profit sectors.

Competing interests None declared.

Patient consent for publication Consent obtained directly from patient(s)

Provenance and peer review Not commissioned; externally peer reviewed.

Case reports provide a valuable learning resource for the scientific community and can indicate areas of interest for future research. They should not be used in isolation to guide treatment choices or public health policy.

\section{ORCID iD}

Nupur B Patel http://orcid.org/0000-0001-9929-0391

\section{REFERENCES}

1 Pal P, Ray S, Moulick A, et al. Liver abscess caused by Burkholderia pseudomallei in a young man: a case report and review of literature. World J Clin Cases 2014;2:604-7.

2 Moawad F, Truesdell A, Mulhall B. A "fishy" cough: hepatobronchial fistula due to a pyogenic liver abscess. N Z Med J 2006;119:U1906.

3 Lee Y-L, Lee SS-J, Tsai H-C, et al. Pyogenic liver abscess caused by Burkholderia pseudomallei in Taiwan. J Formos Med Assoc 2006;105:689-93.

Copyright 2021 BMJ Publishing Group. All rights reserved. For permission to reuse any of this content visit

https://www.bmj.com/company/products-services/rights-and-licensing/permissions/

BMJ Case Report Fellows may re-use this article for personal use and teaching without any further permission.

Become a Fellow of BMJ Case Reports today and you can:

- Submit as many cases as you like

- Enjoy fast sympathetic peer review and rapid publication of accepted articles

- Access all the published articles

Re-use any of the published material for personal use and teaching without further permission

Customer Service

If you have any further queries about your subscription, please contact our customer services team on +44 (0) 2071111105 or via email at support@bmj.com.

Visit casereports.bmj.com for more articles like this and to become a Fellow 